\title{
Utilities of Selected Yogic Practices In Health-Related Fitness
}

\author{
Ganguly SK* \\ GS College of Yoga \& CS, India
}

*Corresponding author: Ganguly SK, Principal (Retd.), GS College of Yoga \& CS, Kaivalyadhām, Lonavla, India.

Received Date: March 05, 2019

Published Date: March 19, 2019

\begin{abstract}
The ultimate aim of all cultural practices of Āsanās is to produce psycho-physiological balance in various systems working in an individual. Proper organic function depends upon three important factors i.e.: a) Uninterrupted supply of nutrients to the tissues of the body through blood supply with healthy functioning of endocrine glands, b) Proper elimination of waste products and c) Better functioning of nervous system. Āsanās like Bhujagāsana, Shalabhāsana and Dhanurāsana etc. help a lot in this regard. Here the backward (Paschima) muscles are contracted and frontal muscles are stretched, while in Paschimotāna, the posterior muscles are wonderfully stretched. Uddiyāna, Nauli help the diaphragm to be raised thereby giving good massage from downward to the heart. Practices like Bhujagāsana, Salbhāsana, Dhanurāsana, alternatively exert pressure on heart. b) Healthy respiratory muscles with elasticity wherein no air cell should remain idle. c) Cleansed respiratory passage. In this context, Uddiyāna, Nauli and Kapālbhāti help a lot to build-up respiratory muscles powerful. Deep inspiration in Shalabhāsana and Dhanurāsana and deep expiration in Uddiyāna and Nauli help to build up elastic respiratory muscles while Kapālbhāti cleanses the respiratory passage forcefully. As far as the adrenals are concerned, this is made active through Bhujagāsana, Shalabhāsana, Dhanurāsana, Uddiyana and Nauli practices. The practices especially like Shirshāsana, Vipritakarani, and Sarvāngāsana work wonderfully for better venous return. These Yogic practices are not available in Physical education programmes or even in sports [1].
\end{abstract}

Keywords: Cultural practices; Health and fitness; Physical education; Yoga

\section{Introduction}

For the last one or two decayed, yoga in the form of Philosophy as well as Science is becoming very popular [2]. In this context, some good works in both the fields have been done in India and abroad in the past. In the past, in an International Yoga Conference held at Kaivalyadhām, various research workers also suggested the utilities of the same $[3,4]$. Therefore the purpose of this paper is to bring out a few rational of these practices from utility point of view.

The ultimate aim of all cultural practices of Āsanās is to produce psycho-physiological balance [5] in various systems working in an individual. The key point is on spinal cord movements [6] at all possible levels (i.e. forward, backward, sideways, twist/torsion) and finally having an impact on higher system.

All the meditative poses are having broad base and list resistance is given to the body against center of gravity and thereby controlling over BMR, Heart rate, pulse rate and thereby preparing a good background for Pranayama and higher practices.
Proper organic function depends upon three important factors i.e.: a) Uninterrupted supply of nutrients to the tissues of the body through blood supply with healthy functioning of endocrine glands, b) Proper elimination of west products and c) Better functioning of nervous system.

Movement of abdominal wall for 24 hours through proper inhalation and exhalation due to breathing has got an impact over regular massage over organs situated in the same. This is further regularized by the yogic poses like Uddiyāna, Nauli and Agnisāra and various Āsanas.

The diaphragm goes down and forward in each inhalation say about 16 to 18 times per minute by helping digestive organs. This can happen only when abdominal muscles are strong enough and elastic. If they are not, the end result will be indignation. Dyspeptic people found to be either very rigid in abdominal muscles or too weak. 
Circulatory System has got the work of sending nourishment to the cell and tissues. The arteries, veins, capillaries and heart are the sole agent through which blood is circulated. Uddiyāna, Nauli help the diaphragm to be raised thereby giving good massage from downward to the heart.

Practices like Bhujagāsana, Salbhāsana, Dhanurāsana, alternatively exert pressure on heart. The first stage of Vipritakarani, Sarvāngāsana also give good positive (+) pressure to heart and thereby help in increasing the efficiency of the same.

Since the veins are the weakest of all and for twenty-four hours, they have to work to return the impure blood (Blue Blood) back to the heart, they have got lot of workload upon them. They are being helped by topsy-turvy practices mainly. As a result, an individual suffering from varicose vain gets lot of help and the pain cum swollen condition is reduced for they are externally helped [7].

Proteins, fats, sugar and salts are distributed to all the tissues once circulatory system is helped. At the respiratory muscles, the lungs also get better exercise when one does Bhujagāsana, Shalabhāsana, Dhanurāsana, and Mayurāsana. Thereby all the cells get oxygenated. To have this, three conditions are to be fulfilled: a) both the lungs should be in good condition and powerful. b) Healthy respiratory muscles with elasticity wherein no air cell should remain idle. c) Cleansed respiratory passage. In this context, Uddiyāna, Nauli and Kapālbhāti help a lot to build-up respiratory muscles powerful. Deep inspiration in Shalabhāsana and Dhanurāsana and deep expiration in Uddiyāna and Nauli help to build up elastic respiratory muscles while Kapālbhāti cleanses the respiratory passage forcefully. Nasal passage obstruction may be due to chronic nasal cataract and deviated septum, mucus etc. The first two cannot be dealt with, but mucus can be eliminated by various Kriyās like Kapālbhāti, Danda, Vastra Dhauti, Jala and Sutra Neti.

Although cases like adenoids, deviated septum, populous cannot be tacked but some Āsanās and other practices that deal with tonsils are Vipritakarani, Sarvāngāsana, Matsyāsana, Simhamudrā, and Jihvā-Bandha. The nasal catarrh also is benefited with these.

Even though, to a great extent Āsanās help in sending nourishment to each cell through the improvement of respiratory and circulatory enhancement, never the less, endocrine glands also become very much active. Proper glandular secretion is also necessary to have better health and fitness of an individual. Once any one of the glands is inactive, one has to face the serious problem in life. In this context Āsanas like Vipritakarani, Sarvāngāsana, Matsyāsana and mudras like Simha mudra and Jihvābandha help a lot to take care of the same so far thyroid gland [7] is concerned. While, pineal and pituitary glands are taken care of through Shirshāsana. As far as the adrenals are concerned, this is made active through Bhujagāsana, Shalabhāsana, Dhanurāsana, Uddiyāna and Nauli practices. To look after the male and female endocrine glands like testes and ovaries, Sarvāngāsana, Uddiyāna and Nauli work very efficaciously. So, the above yogic practices help maximally in maintaining the organic functions of the body.

The waste products (malas) as impurities are regularly are to be eliminated from the body as they create toxins. If the impurities (malas) remain inside the body, it becomes poisonous and one suffers from various illnesses. Herein, three important systems like respiratory, digestive, and excretory (elementary cannel) should be kept cleansed. In this context, practices like Jala Neti, Vastra, and Danda, Basti Kriyās are effective cleansing practices (dhauties) to take care of such systems.

Finally the nervous system is equally important to be taken care of to have efficiency in all walks of life and individual. The practices especially like Shirshāsana, Vipritakarani, and Sarvāngāsana work wonderfully for better venous return. These Yogic practices are not available in Physical education programme or even in sports [1].

This is not exhaustive utility of yogic practices as such. The selected yogic practices as a whole could be utilized very effectively in our day to day lives [2,7], for it proves beyond doubts that these yogic practices[8] satisfy almost all the conditions upon which health and fitness lies as proved in a recent study[3].

Lastly, one should not forget at all the old proverb of western and eastern concept saying "A healthy mind in healthy body" and "SariraMadhyamKhalu Dharma Sadhanam". Ultimately, one should not forget that Physical Educationist and Sports personnel [1] are no other than a human being and whose needs are more so far health and fitness are concerned. In fact in war and peace, fitness wins

\section{Acknowledgement}

None.

\section{Conflict of Interest}

No conflict of interest.

\section{References}

1. Ganguly SK (1994) Application of yogic Practices in Physical Education, Souvenir, Calcutta: Rajpur Yoga Welfare Association, India.

2. Ganguly SK (1998) Yogic Researches in Kaivalyadhām-An overview, I.C.Y.Health Centre, Kaivalyadhām, Souvenir, Mumbai, India, pp. 59-68.

3. Bera TK, Ganguly SK, Jolly SR, Gharote ML (1998) Effect of Three Years Yoga Training Programme on Motor Function in school Boys, YogaMimāmsā, Lonavla: Kaivalyadhām 33(2): 1-21.

4. Ganguly SK, Bera TK, Gharote ML (2003) Yoga in relation to Physical Fitness and Academic Achievement of School going boys, YogaMimāmsā, Lonavla: Kaivalyadhām 34(3-4):188-213.

5. Gitananda Giri, Swami (2003) Yoga and Physiological function, Yoga Life, Pondicherry: Icyer,India 34(2): 3-11.

6. Gharote ML (1972) Spine and Yoga, Yoga-Mimāmsā, Lonavla: Kaivalyadhām 15(1): 27-37.

7. Kuvalayananda, Swami (1862) Āsanas, Bombay: Popular Prokashan, India, pp. 113-132.

8. Yogāsanas a Teacher's Guide (1983) Prepared and written by Dr. Ganguly SK, N.C.E.R.T, New Delhi, India, p. 104. 